DOSSIER

Copyright (c) 2016 SBPjor / Associação Brasileira de Pesquisadores em Jornalismo

\section{VALUES OF JOURNALISTS IN RUSSIA:}

\author{
following historical evolution and \\ modern empirical data
}

\author{
DMITRY GAVRA \\ St.-Petersburg State University, Russia \\ DMITRY STROVSKY \\ Ural Federal University, Russia
}

\begin{abstract}
This article investigates professional values shaped in the Russian journalistic community. The main attention is paid to the historical development of these values and their transformation in post-Soviet Russia. The comparative analysis of different historical periods helps to highlight how journalistic values changed. The authors envisage the results of their empirical survey, conducted in two Russian cities: St. Petersburg and Ekaterinburg. The former relates to metropolitan cities whereas the latter can be attributed to provincial cities, and this defines serious differences in values consumed by their journalists. The survey itself was carried out within the international research project 'Media Systems in Flux: The Challenge of the BRICS countries" supported by the Academy of Finland for 20122016. The authors also discuss the outlines of journalism as a social actor and independent profession given the context of modern media evolution and new information trends following the appearance of online and digital media.
\end{abstract}

Key words: Society. Historical traditions. Media culture. Journalism. Journalistic values.

\title{
VALORES DOS JORNALISTAS NA RÚSSIA: evolução histórica e dados empíricos modernos
}

RESUMO - Este artigo investiga os valores profissionais que definem a comunidade jornalística russa. Uma atenção especial foi dada ao desenvolvimento histórico desses valores e sua transformação na Rússia pós-União Soviética. A análise comparativa de diferentes períodos históricos ajuda a destacar as mudanças nos valores jornalísticos. Os autores apresentam os resultados de uma pesquisa empírica, conduzida em duas cidades russas: São Petersburg e Ekaterinburg. A primeira representa as áreas metropolitanas enquanto a segunda faz referência às cidades provincianas. Essa distinção resulta em diferenças expressivas na forma como os valores profissionais serão interiorizados pelos jornalistas. A pesquisa foi conduzida no âmbito do projeto de pesquisa internacional Media Systems in Flux: The Challenge of the BRICS countries", financiado pela Academia da Finlândia entre 2012-2016. Os autores também discutem os contornos do jornalismo como um ator social e como uma profissão independente no contexto da evolução mídia e da informação noticiosa nos dias de hoje, resultado da emergência da mídia on-line e digital

Palavras-chave: Sociedade. Tradições históricas. Cultura midiática. Jornalismo. Valores Jornalísticos. 


\section{VALORES DE LOS PERIODISTAS EN RUSIA: desarrollo histórico y datos empíricos modernos}

RESUMEN - Este artículo investiga los valores profesionales formados en la comunidad periodística rusa. Se presta especial atención al desarrollo histórico de estos valores y su transformación en la Rusia post-soviética. El análisis comparativo de los diferentes períodos históricos ayuda a resaltar cómo han cambiado los valores periodísticos. Los autores anticipan los resultados de su estudio empírico, realizado en dos ciudades de Rusia: San Petersburgo y Ekaterimburgo. En el primer caso, el estudio se refiere a ciudades metropolitanas mientras que el segundo caso se puede atribuir a las ciudades de provincia, y esto define diferencias sustanciales en los valores consumidos por sus periodistas. La encuesta propiamente dicha se llevó a cabo dentro del proyecto de investigación internacional "Sistemas mediáticos en flujo: el desafío de los países BRICS", apoyado por la Academia de Finlandia entre los años 2012-2016. Los autores también discuten los contornos del periodismo como un actor social y profesión independiente, dado el contexto de la evolución de los medios modernos de comunicación y las nuevas tendencias de la información a partir de la aparición de los medios digitales y en línea.

Palabras clave: Sociedad. Tradiciones históricas. Cultura mediática. Periodismo. Valores periodísticos.

\section{Introduction}

When dealing with spiritual values of journalists it is worth looking not only in the contemporary situation in the media sphere but also at historical frameworks under which these values evolved and got modified. In this regard, it is appropriate to tell about valuable traditions which cement the substance of society and make it a vivid mechanism of social transformation.

Traditions in any society play an extremely important, albeit not always noticeable, role for understanding contemporary political priorities of a country. Besides, these traditions are embodied in professional motivations of journalists as well as in forms of media organization. Integrity between cultural, on the one hand, and journalistic on the other one enables to maintain succession in the media sphere and, to be more precise, between different generations of journalists and creates the certain background for the inheritance of values. In order to draw attention of the audience to their informational products, editorial offices keep projecting 
spiritual and moral values of society which are being reflected in the media content and genres specifics. This cohesion between the past and the present investigated through journalistic practice looks perspective because it creates comprehension of the traditions and their contemporary modifications which can be applied to many humanity studies including journalism research.

Speaking about journalistic values it is worth taking into account that they gradually evolve as a part of national spiritual culture since they always act as specific signs of its existence. As Carey noted, actualization of culture includes the sharing of aesthetic experience, religious ideas, personal values and sentiments, and intellectual notions - a ritual order (CAREY, 1992 , p. 43). Although values seem to be only one of the above elements of culture, their importance for understanding the latter look undisputable. It is true that values in any society seem to be numerous and diverse but the main task always is to figure out most significant of them so that the scenario of national development could be envisaged more profoundly.

Journalistic values can be determined within cultural values given that media themselves are supposed to be part and parcel of spiritual culture. The role of the media becomes pivotal in terms of cultural development of the nation due to its active involvement in cultural life. Culture cultivates daily realities in a particular, mostly emotional, way; otherwise, its values will very unlikely to be clearly reflected in consciousness of people. As for the media, they play first fiddle in portraying these realities because no other political and/or spiritual institution seems to be more important concerning the scale of influence on people's minds and feelings. The role of the media is pivotal in terms of shaping spiritual culture of the nation, and their influence on public is more noticeable then promoted by any other state body. This makes the media and journalists as a very convenient for understanding main priorities of society.

\section{Journalistic values in Russia before 1917}

If one tends to understand the core of Russian life and, consequently, Russian journalism originated from the early 18 century, it is worth taking into account the authoritarian tradition being an 
alienable part of the nature of political powers and simultaneously stamina for the media existence. A strong authoritarian tradition resulted in a lack of parliamentary system in Russia was born long before the appearance of the first media outlets and became a backbone for the media evolution which was expressed in strong hierarchical subordination. The right of the powers was universal in Russia, and journalists were also a part of this political and moral suppression. As Russian philosopher-emigre Leontovich noted, long before 1917 Russia had demonstrated the 'example of the police state' under which freedoms as such were severely restricted. The abolition of serfdom in 1861, unlike the predictions of the Russian liberals, has not changed traditional political and social relations between the authorities and the masses because the monarchy still kept entitling the existence of an absolutist state which continued to be a backbone of Russian life in all regards (LEONTOVICH, 1995, p. 1-4). Pipes also stresses that despite progressive economic changes that occurred by the late 19th century, the main public institutions continued to be under the control of the apparatus of state security (PIPES, 1993, p. 79).

Through the above political limitations which undoubtedly affected life of every individual, it is possible to observe the state of the Russian media and the values inherited by journalists. It goes without saying that the media evolution has never progressed as favorable for journalism freedom. Following the overall media dependence on the powers it was not surprising that all first governmental decrees approved in the 19th century towards the press were called as the statutes of censorship, unlike the statutes of the press freedom adopted in the same time in most Western European and Scandinavian countries. The idea of controlling the press through restrictive law was typical for the Russian authorities. Choldin fairly notes that this idea was greatly important for managerial regulation during the entire period of the media development in this country (CHOLDIN, 1985, p. 25-30). The Russian authorities tended to fix their unhampered right to dominate over journalism and to purposefully influence the public. This particularly affected everyday priorities of the journalistic profession. Moreover, unlike the West, where the press was initiated by economic competition and functioned within a growing system of private interests, Russian media functioned in a completely different context while evolving as mainly a political tool (SIMONS \& STROVSKY, 2006, p. 196). 
It can be well seen on the examples of the first publications, pioneered by the newspaper Vedomosti. It was established in December 1702 by the personal decision of Peter the Great, the first Russian Emperor who also became its main editor until his demise in 1725. Peter scrupulously controlled the content of the newspaper which was a tool of propaganda in the interests of the Russian state rather than a source of non-partisan information. Public interests, in turn, were never taken into account. The most part of Vedomosti consisted of news telling about the successes of the Peter's Russia whether they concerned international politics or, say, military affairs. Later a number of similar state-owned publications have increased not only in St-Petersburg and Moscow but also in the province. All these newspapers and journals were secured financially by the government which patronized them financially. The state press was an undisputable priority against other types of the outlets, and this was a good illustration of the main tendency in the national media landscape.

The above picture directly affected professional standards and values in the media. Journalists had to stand up for the state interests and to ignore everything that was apart from this trend. It elaborated their specific style of thinking under which the entire world was narrowed by political limitations. Having no plurality in grasping facts journalists positioned themselves as expressers of the state will which had a strong impact on the readership. Therefore, on the other hand, they were 'legalized' to speak out taking into account the governmental viewpoint on the 'picture of the world' but, on the other hand, incontestable authority of the Russian state and the media dependence on it was giving journalists an opportunity to usurp their right to be undisputable oracles favoring the Russian Empire and its rulers.

It would be wrong to claim that all the publications in Russia were state-regulated. Since the mid-19 century a number of private outlets also started to grow and in a few decades the press system became very diversified, in a formal way similarly the analogies in Western European countries. In the meantime, the concept of media pluralism was accepted publicly if only it pretended to be helpful for the state; the ability of journalists to think independently was neglected and even suppressed. To be honest, the level of plurality could never elaborate the standard of polemics on political issues in Russian society compatible to that in the West. Time by time, true, 
Russian journalists tried to put serious matters on agenda but as soon as a discussion threatened to come out or even destroy the priorities of the state, it was ceased.

Thus, journalists in Russia were traditionally fully attached to the priorities of the powers. All this clearly represented a certain type of political thinking shaped in their consciousness. In order to figure it better, it is worth stemming from typology of political culture initiated by Almond and Verba as early as in the mid-1960s. Following their fullscale research made on the examples of a few countries they defined the three types of political culture influencing political behavior of people including journalists: patriarchal which seems to illustrate a lack of public interest to political life; servile under which the state fully undermines consciousness of the people, and they seem to be passive in political life of society, and activist which demonstrates an increased interest of this society to politics and simultaneously a high degree of its informing about current changes (ALMOND \& VERBA, 1964). This classification does not seem to have lost its actualization in the contemporary conditions, and thanks to its universal background looks adoptable for the observation of historical and cultural development of any society as well as of mentality of journalists.

Due to the subversive impact of the powers on society in Russia, most of its population paid too little interest to certain political practice. Journalists seem to have been somehow different about their reflections towards politics (due to the profession itself), however, their servility and non-criticism to the authorities were very obvious. The press, to the most part, ignored discussions of pivotal issues, and their degree of personal freedom depended, first of all, on the will of a monarch and his subordinates as the bearers of the highest state power. Following this, it is possible to claim that Russia has inherited a servile type of political culture, and journalists considered it as inevitable for the fulfilment of their purposes.

\section{Values as a part of ideological mechanism: the soviet period}

Despite different social and political frameworks that occurred in Russia before 1917 and after, journalists inherited similar values. Most important was the 'attachment' of these journalists to the state. The authoritarian tradition developed in new political conditions, under the Soviets, was even reinforced 
and became dominant in everyday media practice. Consequently, Soviet journalists who in many ways seem to have been neglected the pre-revolutionary period by the lack of press freedom, were involved in the same scenario of political management. This similarity can be explained by the same type of hierarchy laid down by the regime.

The Soviet government in all levels of the political hierarchy always paid a particular attention on shaping communist consciousness in journalistic community. This process evolved through the large-scale mechanism of propaganda, established by the Bolsheviks immediately after their coming to power. The mechanism itself applied not only to journalists but operated through various forms of art: literature, theatre, cinema, etc. It would be right to say that propaganda penetrated every cell of the social mechanism by enlightening people about 'proper understanding' of the political situation in the country. The penetration of propaganda into the mindsets of the Soviet people was, in fact, very influential and encompassed every social stratum, from children to old men. The media, in turn, were regarded by the Bolsheviks as an effective and integrated tool of promoting certain political ideas. Against this background, journalists played a very specific role due to the largely developed system of the mass media initiated by the authorities as early as at the dawn of Soviet power. The specific media coverage based on the principles of proletarian ideology helped the authorities in promoting propaganda ideas. The media helped journalists to gradually influence the masses and to create in their consciousness the perception of rightfulness of life.

A main task for Soviet journalists was defined primarily by political expediency. The protection of the idea of the Bolshevik revolution and discrimination of political opponents looked as the priorities for the journalistic profession. Lenin wrote in this regard: "It is necessary under the dictatorship of the proletariat to re-educate millions of peasants and small owners, hundreds of thousands of employees, officials and bourgeois intellectuals, to subordinate them all to the proletarian state and to proletarian leadership, defeat them in bourgeois habits and traditions" (LENIN, 1979, VOL. 41, p. 102).

As a result, journalists in the Soviet Russia saw their professional obligations not only in terms of providing sociallyoriented information but also considering themselves as the front 
line soldiers of the Communist priorities. Their activities were aimed, one way or another, on full-fledged transformation of social relations in the country. The political role of journalists was especially influential in the fulfillment of this process. Immediately after 1917 the mass media became a specific social institution as being the tool of political management of masses. According to this, journalists played a very specific role making functions of the journalistic profession as subordinated to the Communist Party hierarchy. In the Soviet time these functions were entirely dependent on certain political interests. A pivotal task for journalists therefore was not only non-partisan informing but ideological upbringing of the audience.

When envisaging journalistic values after 1917, it is possible to grasp them as the perfect result of a long Russian evolution to the state centrism. Within this tradition a journalist seems to have been personally neglected by political practice. On the one hand, his/her work was treated individually but simultaneously seen as necessary for reaching global purposes. A journalist facilitated to strengthening certain political behavior and motivations of Russian society. This enables to better see logical continuity of the pre-revolutionary traditions of the authoritarian political powers and shaped later the frameworks of the totalitarian political regime. This continuity was earlier envisaged by Russian philosopher Berdyaev who in the 1930s called totalitarianism as an inevitable element of Russian political life (BERDYAEV, 1990). The same was noted a few decades later by Arendt considering it as a logical continuation of the Communist idea (ARENDT, 1961).

The post-revolutionary development of the authoritarian tradition has been labeled in the pivotal principles of journalism functioning under the Soviets:

1. The principle of party spirit;

2. The principle of class character;

3. The principle of consensus between the power and the people.

The principle of party spirit which was basic for the elaboration of journalistic values demanded that journalists follow the party dogma and defined the organizational structure of the media with outlets of the lower party committees subordinating themselves to those of the higher party committees. The principle of class character, in turn, determined a specific type of a hero in the 
media who had to represent either a worker or a poor peasant and much more rarely people originating from intelligentsia. Finally, the third principle facilitated the appearance of many letters from the socalled 'average readers', who again had to be workers or peasants.

Remarkably, these principles of the media existence in the Soviet Union were noticeable as late as during Gorbachev's perestroika and glasnost in the mid-1980s. This illustrated not only the specific media content but also the values confessed by journalists themselves. The latter still turned out part and parcel of the existing political hierarchy although the political situation in different periods of the Soviet history was different. True, journalists became freer with their intentions to reveal the problems of society; meanwhile, the mechanism of media management has not changed in those years. Correspondingly the values of most journalists have been only slightly modified especially as most of reporters kept on serving for the party media. The private media have not been circulating largely in those years.

The situation started to thoroughly change only in the 1990s when Russia made first steps to market reforms. The rapid transformation of political and economic realities in the country that occurred during the last two decades has been imprinted on journalistic values which became more plural and diverse. Although current Russian President Putin is doing much to strengthen his personal power and to gain unconditional obedience from the lower to higher levels of authority, the journalists seem to show that they are no longer prescribed to integrity values as before. This distinction between the states of journalistic values before and nowadays serves as a good illustration of the fact that Russia no longer lives in the traditional world, and the representations of journalists about their professional priorities and themselves became different.

\section{Method of investigation}

In order to prove the above idea the authors resorted to the case studies carried out in St. Petersburg and Ekaterinburg.

Saint-Petersburg is the second Russia's largest city having received an informal status of the 'cultural capital' or 'Northern capital'. This city was the capital of the Russian empire in 
XVIII - early XX centuries indeed, and from here the Communist transformation of Russia started. In the 1930-50s St-Petersburg has suffered greatly from the purges, resulted in a great number of sacrifices. During World War II the city was surrounded by the Nazi troops and experienced a famous siege which continued for almost three years, following more than 1000000 victims $^{1}$. Today St-Petersburg is populated with more than 5 million people. It is the mother city of the current Russian President Vladimir Putin and his predecessor Dmitri Medvedev. St-Petersburg is also known as a city with influential liberal opposition, which was especially active in 2011-2012.

Ekaterinburg, in turn, is the city called as an industrial backbone of Russia. It is located in the Urals (two hours flight east of Moscow) and has a population of 1.3 million people. Although unlike metropolitan St-Petersburg, Ekaterinburg can be labelled as a provincial city, it tends in all regards to be more noticeable than most of provincial centers in Russia. Here was the birth place of the first Russian President Boris Yeltsin who proclaimed market reforms in the country since the early 1990s, immediately after the collapse of the Soviet Union. Today Ekaterinburg is one of the most developed cities in Russia including market opportunities in different spheres and particularly in the media, and also known for its support of liberal opposition.

Empirical data for the investigation of journalistic values in the both cities came from in-depth semi-structured interviews conducted with 49 journalists. The St-Petersburg sample included 12 leading mainstream media and 12 new Internet-based media. The study itself was carried out with the support of the Journalism Faculty of St-Petersburg State University. The data in Ekaterinburg was based on the interviews with 24 journalists (equally from traditional and new media) and assisted by the Journalism Faculty of the Ural Federal University. The online media consisted of 5 information agencies and online newspapers as well as 1 online TV-channel. Among off-line media there were 1 regional newspaper, 2 magazines, 2 broadcasting TV-channels and 1 radio.

The whole research was divided in three dimensions: 1) conventional media and new internet-based media; 2) national media and regional media; 3) different types of media: newspaper, magazine, radio, television and the registered internet media. The authors also took into account media subcategories: quality (citizen-oriented) and popular, ownership: state/public, private 
and mix: state \& private. Quality media are traditionally citizenoriented, and their reputation mostly stems from their agenda setting function in the media system. Popular media are mostly consumer-oriented, and their success is strongly dependent on their ability to attract a large audience. In turn, state media are understood as the media with over $50 \%$ of direct or indirect assets being received from the government. Among the quality media we dwelled upon those with the highest profile; among popular media the selection was made on those having the biggest audience.

In each media two journalists were interviewed. Each interview continued about 90 minutes. The journalists were asked about a few main topics: 1) differences between the professional practices and status of traditional and online media; 2) political, professional and ethical priorities of journalists, including their attitudes towards political protests; corruption in the media system; usage of social networking in professional and everyday life of journalists.

This set of topics afforded to understand pivotal values of the journalistic communities in St-Petersburg and Ekaterinburg which became greatly important for the evaluation of the contemporary motivations of those working in the profession.

\section{Findings}

The main question which was set on agenda concerned the attitude of journalists to their profession.

Deuze, Blank, and Speers (2010) when observing convergence of production and consumption in different media companies came to conclusion that Internet suggested new possibilities for mass-media and simultaneously changed the 'make-up' of traditional journalism. The old priority has been added with a new phenomenon: on-line journalism. Correspondingly, it provoked the question about the status of on-line journalism as well as about the relationships between the traditional and on-line media. Researchers and media-practitioners initiated the discussion about the essence and future position of Internetjournalism having raised an issue on instrumental priorities of traditional media and new type of journalism (DEUZE, 2003; PAVLIK, 2001; PRYOR, 2002; WARD, 2002). The question still 
remains: if on-line journalism seems to be a manifestation, albeit specific, of traditional journalism, or it defines a new practice, going far beyond the habitual frameworks. For instance, Mark Deuze suggests that the main traits of on-line informing (hyper textuality, interactivity, multi-mediality) lead to profound changes within the journalism profession (DEUZE, 2003).

The second idea stresses vital importance of the geographical factor which affects the state of the media. The concept of so-called 'Four Russias' by Natalya Zubarevitch indicate geo-economical and geo-political factors as explaining socio-political dynamics of modern Russia (ZUBAREVITCH, 2009). According to this concept, modern Russian society is pierced by four different information flows. The makeup of these flows depends on the type of the region which determines disparities for the media development. St-Petersburg and Ekaterinburg seem to belong to different clusters thanks to dissimilar territories, psychologies, cultural trends, etc.

The authors' hypothesis assumes that the type of media (traditional vs. new) and geo-factor generating certain political and organizational differences between Russian cities (metropolitan vs. provincial) are significant in determining different attitudes of journalists living there to their profession.

Below are some empirical data received during our investigation. In order to make them more understandable it is worth making up a few tables anticipating with the questions being related to the clarification of values of journalists.

\section{Status of journalists}

Table 1 - 'Are journalists in traditional and new media different?' (\%)

\begin{tabular}{|c|c|c|c|c|}
\hline Region & \multicolumn{2}{|c|}{ St-Petersburg } & \multicolumn{2}{c|}{ Ekaterinburg } \\
\hline Media type & on-line & traditional & on-line & traditional \\
\hline No & 67 & 50 & 22,2 & 10 \\
\hline Yes & 33 & 50 & 77,8 & 90 \\
\hline
\end{tabular}

Source: elaborated by the authors. 
Compared to St-Petersburg, both traditional and new media journalists living in Ekaterinburg are sure that such difference exists. 90\% of Ekaterinburg respondents from traditional media feel the distinctions between themselves and their colleagues from online media. Vast majority (77.8\%) of their on-line media colleagues have the same opinion. Quite opposite are the answers of St-Petersburg journalists. Two of every three on-line journalists (67\%) see no difference between journalists working for different types of the media. Traditional media journalists in St-Petersburg are split (50\%) when answering this question.

\section{Journalists' job satisfaction}

Table 2 -What does bring professional job satisfaction for you?' (\%)

\begin{tabular}{|c|c|c|c|c|}
\hline Region & \multicolumn{2}{|c|}{ St-Petersburg } & \multicolumn{2}{|c|}{ Ekaterinburg } \\
\hline Media type & on-line & traditional & On-line & traditional \\
\hline $\begin{array}{l}\text { Creative work and } \\
\text { self-realization }\end{array}$ & 22 & 32 & 27,3 & 58,3 \\
\hline $\begin{array}{l}\text { Thanks from } \\
\text { audience and } \\
\text { feedback }\end{array}$ & 26 & 20 & 27,3 & 25,0 \\
\hline $\begin{array}{l}\text { Materials of high } \\
\text { quality }\end{array}$ & 17 & 16 & 9,1 & 16,7 \\
\hline $\begin{array}{l}\text { Respect and } \\
\text { acknowledgement } \\
\text { from colleagues }\end{array}$ & 22 & 4 & 9,1 & 8,3 \\
\hline $\begin{array}{l}\text { Ability to influence } \\
\text { and to change smth. }\end{array}$ & 4 & 16 & 9,1 & 8,3 \\
\hline $\begin{array}{l}\text { New knowledge and } \\
\text { new people }\end{array}$ & 0 & 0 & 27,3 & 25 \\
\hline
\end{tabular}

Source: elaborated by the authors.

In terms of job satisfaction there is a slight difference between metropolitan and provincial media journalists as well 
as between new and traditional media journalists. For each sub-group the most important predictors of job satisfaction are 'creative work and self-realization' (ranking 1), 'gratitude from the audience and feedback" (ranking 2). Only in the third ranking the geo-factor is noticeable. For St-Petersburg the third most important predictor of the job satisfaction are 'materials of high quality', while for the Ekaterinburg journalists the most pivotal factor is 'new knowledge and new people'. This is explained in the direct speech of the informants: St-Petersburg seems to suggest for a journalist much broader opportunities to get new knowledge and to meet new people. The structural type of the media hypothesis, thereby, has been verified. In St-Petersburg for the on-line journalists the importance of 'respect and acknowledgement from colleagues' predictor of job satisfaction is 4.5 times higher than for their off-line media colleagues. On the contrary, for Ekaterinburg traditional media journalists 'creative work and self-realization' is twice as more important for the job satisfaction as compared with on-line journalists.

\section{Professionalism}

Professionalism is regarded as a crucial point of selfdetermination of journalism as a social function as well as the professional occupation. In the survey we asked our informants opened questions about the main features and criteria of journalists' professionalism. Results were sometimes striking.

According to our primary hypothesis, both the media type and geographical factor affect the profession, and this prediction was verified. Sub-samples in both regional and media-type dimensions differed greatly. The divergence was so remarkable that even raised the question if Russian journalists can be considered as a professional community. It became clear that in terms of professional cultures there is an obvious difference not only between St-Petersburg and Ekaterinburg journalists, but also between those working for online and off-line media within the same territorial communities. Even on-line journalists of the same age and similar social experience, but living in different parts of Russia are distinctive about their understanding of professionalism.

In terms of professionalism, the geo-factor looks more 
significant than the type-of-media factor. Seeing this difference we figure out each sub-group separately, comparing it with another.

The survey showed that on-line and off-line journalists in St-Petersburg have different structural models of professionalism. In some way they are very similar but not always. The tables show the distribution of the most important features of journalist's professionalism, ranked by each group.

Table 3 - Professionalism: St-Petersburg traditional media journalists

\begin{tabular}{|l|c|c|}
\hline $\begin{array}{l}\text { Features and properties of professionalism in } \\
\text { journalism }\end{array}$ & Ranking & $\%$ \\
\hline good education and general erudition & 1 & $29 \%$ \\
\hline competence and knowledge of the subject & 2 & $21 \%$ \\
\hline honesty, sincerity & $3-5$ & $8 \%$ \\
\hline ethical behavior, professional ethics & $3-5$ & $8 \%$ \\
\hline objectivity & $3-5$ & $8 \%$ \\
\hline
\end{tabular}

Source: elaborated by the authors.

Table 4 - Professionalism: St-Petersburg on-line journalists

\begin{tabular}{|l|c|c|}
\hline $\begin{array}{l}\text { Features and properties of professionalism in } \\
\text { journalism }\end{array}$ & Ranking & $\%$ \\
\hline writing and technological skills & 1 & $32 \%$ \\
\hline good education and general erudition & 2 & $18 \%$ \\
\hline honesty, sincerity & $3-6$ & $9 \%$ \\
\hline competence and knowledge of the subject & $3-6$ & $9 \%$ \\
\hline independence, non-venality & $3-6$ & $9 \%$ \\
\hline courage, stubbornness & $3-6$ & $9 \%$ \\
\hline
\end{tabular}

Source: elaborated by the authors. 
In St-Petersburg both groups as most important professional features and properties of the journalist were marked:

- good education and general erudition;

- honesty, sincerity;

- competence and knowledge of the subject;

- courage, stubbornness;

- refusal to excel, stand out at the expense of human problem, personal tragedy.

It is remarkable that St-Petersburg traditional media journalists fully ignored such professional property as 'writing and technological skills'. While in the group of new media journalists these 'professional skills' gained a leading position. The only explanation of this paradox is that experienced and more aged off-line journalists regard writing skills as evident unconditional prerequisite of the journalism profession. Therefore they didn't even mention it. This conclusion could be proved by the answers of traditional media journalists about the most unprofessional characteristics. For them the worst for journalists in terms of professionalism are lack of education, writing skills and incompetence ( $87 \%$ of the answers).

For St-Petersburg on-line journalists their involvement into new media and permanent access to new technologies is of vital importance. One of every three respondents from this sub-group specially underlined 'technological skills'. It is clearly understandable, because online media positions enable journalists to be qualified in WWW interfaces, software products, mobile applications, etc.

Among traditional media journalists nobody specially stressed importance of independence, non-venality, while for the representatives of new media this position has got relatively high rating.

Below is ranking of professionalism in Ekaterinburg. 
Table 5 - Professionalism: Ekaterinburg traditional media journalists

\begin{tabular}{|l|c|l|}
\hline $\begin{array}{l}\text { Features and properties of professionalism } \\
\text { in journalism }\end{array}$ & Ranking & $\%$ \\
\hline honesty, sincerity & $1-2$ & 33,3 \\
\hline ethical conduct & 3 & 27,2 \\
\hline competence and knowledge of the subject & 4 & 22,2 \\
\hline independence, non-venality & 5 & 11 \\
\hline writing and technological skills & & 33,3 \\
\hline
\end{tabular}

Source: elaborated by the authors.

Table 6 - Ekaterinburg on-line journalists

\begin{tabular}{|l|c|c|}
\hline $\begin{array}{l}\text { Features and properties of professionalism } \\
\text { in journalism }\end{array}$ & Ranking & $\%$ \\
\hline good education and general erudition & $1-2$ & 37.5 \\
\hline ethical conduct & $1-2$ & 37.5 \\
\hline competence and knowledge of the subject & 3 & 25 \\
\hline honesty, sincerity & 4 & 12.5 \\
\hline writing and technological skills & 5 & 2.5 \\
\hline
\end{tabular}

Source: elaborated by the authors.

We see that some professional trends journalists in StPetersburg and Ekaterinburg treat differently. Some arguments can be explained by dissimilarities in cultural background as well as by professional motivations. Moral principles seem to be more pivotal for Ekaterinburg journalists where as technological skills and professional competences look as a priority for St-Petersburg respondents. In our view, the whole picture depends very much on the educational and cultural backgrounds, and the existence of new technologically developed media trends. The figures also show, at least to some extent, that professional interests and self-identification of journalists 
in metropolitan and provincial cities of Russia evolve specifically which creates a pretty diverse picture of journalistic perceptions and moods.

\section{Functions of journalism}

On-line and off-line journalists are similar about their understanding of journalism functions. However their answers still differ from each other.

Below are the most important functions which journalism should pursue following the ranking estimated by journalists working for traditional media.

1. providing information

2. enlightenment

3. entertainment

4. forming public opinion

5. criticism, finding solutions

As for new media journalists they valued the most important functions differently.

1. providing information

2. entertainment

3. making audience thinking

4. enlightenment

5. propaganda

The overwhelming number of journalists from both new and traditional media, as we see, highlighted the informational function. Such functions as 'formation of opinions', 'interpreting', 'advocacy' and function 'making people thinking' looks much less consumed. In turn, none of the respondents from both new and traditional media mentioned the cognitive function, and only a few reporters from on-line media noted the educational function as important. At the same time, journalists from the both types of media believe that the idea of 'enlightening people' is one of the most fundamental functions. In the meantime, journalists from traditional media name this function twice as more often as those working for the new media. 
These responses can be viewed in a certain way. Journalists of traditional media, especially those who are older and whose professional career began during the Soviet era still see the journalism profession as important for public enlightenment and upbringing. For this reason, journalists from traditional media often referred to the educational-enlightenment function while journalists from on-line media mentioned this function twice as less.

The entertainment function is ranked on the third place among those mentioned by the both groups of journalists. However, on-line journalists underlined 'entertainment' as one of the main media functions unlike off-line journalists. This can be explained that the latter in average are younger than their counterparts from traditional media, and therefore for them infotainment seems to be more habitual.

Journalists from traditional media identified the controlling function while online journalists didn't even mention it. This situation seems to be motivated by two factors: firstly, the traditional media have a long history, and journalists working there can reproduce stereotypes of the social influence. Secondly, most journalists from traditional media were building their careers in the Soviet or early post-Soviet times when a journalist was an influential person carrying out control over social institutions. Journalists from traditional media still believe that the profession must also contribute to finding solutions (constructive criticism).

In the both groups the first ranking belongs to 'reporting news'. Further, there is noticeable difference between old and new media journalists about how they understand the words 'enlightenment' and 'helping people'. Their answers correspond with their comprehension of journalism' functions. Many of journalists still believe in the mission of journalism that they have accepted in the periods of Gorbachev's perestroika and liberal reforms being promoted under Yeltsin. For the journalists working for new media, being developed especially under Russian President Putin, such media roles as 'entertainment' and 'providing analysis' look more suitable. 


\section{Conclusion}

The journalism values in Russia have tremendously changed in the last years when compared with the previous periods of the native history. This is confirmed by the evolution of these values and their impetuous transformation in Russia, at first under President Yeltsin and finally under President Putin. How Russian journalists feel now about their professional involvement and priorities were investigated during the empirical research following the results that had been envisaged in the article.

Unlike the Soviet period, today's journalists in Russia became more independent in their thinking on pivotal issues of the day and no longer create a monolith group which defines similarly professional duties and outlines which they bear. On the one hand it witnesses about a renewed role played by journalists in Russian society. On the other hand, journalists themselves seem to be different from each other in their perceptions on the specifics of the journalism profession. At the same time this situation as such seems to be very contradictory because it confirms inconsistency of the media development in Russia and uncertainties that live in mindsets of Russian journalists. In the meantime, this inconsistency looks as a good way-out from the previous monotonous evolution of the media in this country. Russia still exists in the period of political and social transformation which is absorbed by instability of all institutions, and the media seem to serve as a reflection of this trend.

NOTES

1 http://www.spbumag.nw.ru/2009/08/6.shtml

REFERENCES

ALMOND, G.; VERBA S. The Civic Culture: Political Attitudes and Democracy in Five Countries. Princeton (PJ): Princeton Univ. Press, 1964. ARENDT, H. Between Past and Future; Six Exercises in Political 
Thought. London, New York: Faber \& Faber, 1961.

BERDYAEV, N. Istoki i smysl russkogo kommunisma [The Sources and Essence of Russian Communism]. Moscow: Nauka, 1990.

CAREY, J. Communication as Culture: Essays on Media and Society. London, New York: Routledge. 1992.

CHOLDIN, M. A Fence Around the Empire: Russian Censorship of Western Ideas under the Tsars. Durham, NC: Duke University Press, 1985.

DEUZE, M. he Web and Its Journalisms: Considering the Consequences of Different Types of Newsmedia Online, New Media \& Society, London, Vol. 5(2), p.203-230, 2003.

DEUZE, M.; BLANK, P.; SPEERS, L. Media Life. Working paper. 2010. Available in: < https://scholarworks.iu.edu/dspace/bitstream/ handle/2022/3764/DeuzeBlankSpeers\%20MLv1.pdf?sequence=3> Access on: 05 set. 2015 .

KIRIA I. Regional Disparities in Development of Media in Russia: Building-up a Methodology. Available in: < http://www.hse.ru/ data/2014/06/30/1308648888/regional\%20disparities_kiriya-dovbysh. pdf > Access on: 09 set. 2015.

LENIN, V. Detskaya bolezn' levizni v kommunizme [The children's illness of leftism in Communism]. Vol. 41, 1979.

LEONTOVICH, V. Istoriya liberalizma v Rossii, 1 762-1914 [The history of liberalism in Russia, 1762-1914]. Moscow: SP: Russkiy put', 1995.

PAVLIK, J. Journalism and New Media. New York: Columbia University Press, 2001.

PIPES, R. Rossiya pri starom regime [Russia under the old regime]. Moscow: Nezavisimaya gazeta, 1993.

PRYOR, L. The Third Wave of Online Journalism, Online Journalism Review, 2002. Available in:<http://www.ojr.org/ojr/future/1019174689. php > Access on: 10 set. 2015 .

SIMONS, G.; STROVSKY, D. Censorship in Contemporary Russian Journalism in the Age of the War against Terrorism: a Historical Perspective. European Journal of Communication, Vol. 21, N 2, p. 189-211, 2006.

ZUBAREVITCH, N. V. Territorial Aspect of Modernization, Social policy: expertise, recommendations, reviews, N 10, p. 32-54, 2009.

WARD, M. Journalism Online. Oxford: Focal Press, 2002. 
Dmitry Gavra is professor and deputy dean on scientific and research affairs at the School of Journalism and Mass Communication of St.Petersburg State University (Russia). He is also in charge of the chair of business public relations. Gavra's main interests are focused on sociology and theory of mass communication following his contribution in writing and editing a few books and over 160 articles published in Russian and English in the USA, Germany, Sweden and some other countries. In the previous years he was a visiting professor in many European universities. In addition, Gavra is a member of editorial boards of a few scientific journals being released in Moscow, St.-Petersburg and Stockholm.

Dmitry Strovsky is professor of the Journalism Faculty at the Ural Federal University (Ekaterinburg, Russia). Strovsky's scientific priorities are concentrated on the investigation of Russian media history from the early 20th century onwards, following his numerous publications in professional journals of Russia, the USA, the UK and Taiwan. During the last years Strovsky has intensively lectured at the universities of the USA, China and many European countries. He was a Fulbrighter in 2005 and an interport lecturer of the Semester at Sea (2013 and 2014) initiated by the University of Virginia, and has been awarded with many foreign scholarships for doing research projects. Strovsky is also a regular contributor to Novaya Gazeta being one of very few liberal publications in Russia where he still contributes with his journalistic essays. 